\title{
Notary Role In Making Cooperation Deed Based On Act No. 25 Of 1992 On Cooperatives In The Kudus District
}

\author{
Davit Hari Sanjaya1, Wilmar Ibni Rusydan² and Achmad Sulchan ${ }^{3}$
}

Abstract. The purpose of this study are to: 1) To determine and analyze the role of the Notary In Making Cooperative Deed Based on Act No.25 of 1992 on Cooperatives in Kudus District, 2) To determine the barriers and solutions with other legal regulations. The data used in this research is the primary data secondary data to support the assessment, which is then analyzed by sociojuridical.

Based on data analysis concluded that: 1) The results of this study indicate Notary Role In Making Deed of Cooperative Members ie till Endorsement Process Deed by the competent authority, the Minister, the Act is used in the manufacture Cooperation Deed is the Act No.25 1992. the role of the Notary in making Cooperation Deed stipulated in the Decree of Minister Number 98 / KEP / M.UKM / IX / 2004, in addition to the Basic Law Firm ratification process Cooperatives, Government Regulation No. 4 of 1994 on the Terms and Procedure for Approval of Amendment to Articles of Incorporation Deed Basics Cooperative, and Regulation No. 01 of 2006 that is on Implementation Guidelines for the Establishment, Approval of establishment and amendments of the Cooperative. 2) There are several notaries who are new that have not signed up to become a Notary Deed Official Land should Notary new one immediately enroll into NPAK, in the manufacture of Cooperation Deed Notary still ask for services to prospective Cooperative who can not afford, while at Law Notary is not mandatory enlist the services with the provisions of the Cooperative it was completely incapable and must have a letter from the Village, the reason besides pembuatanya complicated and lengthy the Notary still ask for services but the cost at most minimal, a notary is excluded by the founder and the Department of Cooperatives in meetings of formation, so that each holding Formation meeting cooperative cooperative Division move itself without the presence of a Notary, the Notary should be invited in the meeting included joint founder of the cooperative Formation, in the execution of the Deed of cooperatives, making the slowest period of 3 months and the fastest 7 working days.

Keywords: Notary Role; Deed Making; Cooperative

\section{Introduction}

Notary has been known in our country, since the Dutch colonized Indonesia, because notaria is an institution that is already known in their lives in its own fatherland. The existence of a notary institution in Indonesia is always associated with the presence of the faculty of law, it is evident from the institution that produces everything from fakulttas notary law with a specialty program specialist education program notary present or master study program notaries. ${ }^{4}$ Before entering into the deed notary cooperative, first look at the history of cooperatives after Indonesia's independence. The desire and passion for politics cooperatives destroyed by the colonial Dutch and

\footnotetext{
1 Studens Master of Notary Law, Sultan Agung Islamic University Semarang email davitsanjaya@gmail.com

2 Students of Master of Law, Faculty Of Law, Universitas Islam Sultan Agung email wilmrusyd@gmail.com

${ }^{3}$ Faculty of Law Unissula, Semarang.

${ }^{4}$ Arliman S., Laurensius, 2015, Notaris dan Penegak Hukum oleh Hakim, Deepublish Publisher CV BUDI UTAMA, Yogyakarta, p.2
} 
continued by kumini system on Japanese colonial era, is slowly re-warmed after Indonesia's independence. Especially with the Constitution of the Republic of Indonesia in 1945, in article 33 that establishes cooperative as the pillar of the Indonesian economy, the legal position of cooperatives in Indonesia actually become more stable. And since then Moh.Hatta as vice president of the Republic of Indonesia more intensively strengthen awareness on cooperatives for Indonesia, as well as provide guidance and motivation to the cooperative movement in order to improve the way businesses and ways of working, for services he was then appointed Moh. Hatta as the father of Indonesian Cooperatives. ${ }^{5}$

The role of the Notary in deed cooperatives After the release of Ministerial Decree No. 98 / KEP / M.UKM / IX / 2004, notary deed authorized to create cooperatives. Notary Public involvement is not merely help the process of making the deed of cooperatives, but helped care for cooperative development prospects of its client and willing to provide guidance and legal advice relating to the development of cooperative deed. The goal is that the cooperative movement and the cooperative society increasingly understand and do not lay with the things that smelled of law. Notary deed cooperatives can make up what is agreed upon by the founders of the cooperative in accordance with the legislation which the founders of the cooperative in accordance with the legislation in force. Cooperatives are business entities that organize the use and utilization of economic resources of its members on the basis of the principles of the cooperative and the rules of economic enterprises to improve the lives of members in particular and society work areas in general, thus the cooperative is a popular economic movement and cooperatives bases its activities based on the principle of people's economic movement based on the principle of kinship. ${ }^{6}$

Act 25 of 1992 been replaced by Act 17 of 2012, but the law was canceled because it is a corporation, indifidualisme and capitalists as well as eliminating the principle of mutual assistance. because there is a vacuum laws on cooperatives then re-apply the Act No.25 of 1992 on Cooperative.

Based on the background of the problems above, the Be interested take the title role of the Notary In Making Deed of Cooperative Based on Act No. 25 of 1992 on Cooperatives in Kudus. With the formulation of the problem: The role of the Notary in the Deed Making of Cooperative Development Based on Act No.25 of 1992 on Cooperatives in Kudus District; Obstacles and Solutions in Implementing Cooperation Deed Under Act No. 25 of 1992 on Cooperatives in Kudus District.

\section{Research methods}

This study using sociological juridical approach, the researchers not only applied using the positive law in Indonesia but also interviewed a notary in Kudus, that will obtain concrete results in research and accountable. And in this study favored the existing data in Notary Office in Kudus. Specifications of this research is descriptive qualitative. In this study the primary data, the data obtained directly from investigator sites through direct interviews of informants related. By preparing earlier questions prepared beforehand by the author to which hooked. Secondary data include official documents, books, research results in the form of reports, diary and others. or material which may explain the primary legal materials. Data analysis techniques with kualitatiif, to find the appropriate data in the field to clear the fact that the role of the Notary in the Deed of Cooperative Development is based on Act No.25 of 1992 on Cooperatives in Kudus.

\footnotetext{
${ }^{5}$ Sitepu, C.F. dan Hasyim, 2018, Perkembangan Ekonomi Koperasi Di Indonesia, NIAGAWAN, 7 (2): 58-68.

${ }^{6}$ Cooperatives Decree No. 98 / KEP / M.KUKM / IX / 2004 on Notary Deed Cooperative
} 


\section{Results and Discussion}

\subsection{The role of the Notary In Deed Making of Cooperative Development Based on Act No.25 of 1992 on Cooperatives in Kudus District}

The legal basis of the regulation's role in the implementation of the manufacturing Notary Deed:

Notary Act gives the sense of the Notaries in Article 1 (1) of Act No. 322014 amendment number 30 of 2004 that a Notary is a public official authorized to create an authentic deed stipulated in this Law:

As Notary Public Notary Deed Land, hereinafter abbreviated as (NPAK). NPAK governed by Article 4 of Decree of the Minister No. 98 Of 2004 regarding Notary Public as Cooperation Deed Official, that Notaries are General Authorities appointed under Rule Notary, which were authorized by the government to make the certificate of incorporation, deed of amendment of the articles of association and deeds of others relating to cooperative activities.

Notary main authority contained in Article 15 of the Law Notary be authorized by the government and the Minister of Article 3 that the task of making Notary Deed Authentic as evidence of a certain legal actions in the establishment of Cooperation Deed.

Act 25 of 1992 was the legal basis in the manufacture of Cooperation Deed, although the Act been replaced by Act No. 17 of 2012, but it has come back again to the old law, namely Act No. 25 of 1992 concerning Cooperatives, Because there are several articles that are not in accordance with the principles of cooperatives because there is mutual help but capitalist and is the Corporation that objectives listed in that article solely to seek personal gain

The process of establishment of cooperatives starting with the implementation of the Meeting of the Establishment of Cooperative where for the Primary Cooperative at least attended by 20 founding members, while the Cooperative Secondary at least attended by three (3) cooperative through their representatives (Article 5, paragraph 1), Meeting formation the cooperative was attended by Acting Department / Institution / Agency in charge of local cooperatives in accordance domicile members (Article 5, Paragraph 3), Meeting of Formation will be discussed concerning the Articles of Association of cooperatives which contains, among others (Article 5 Paragraph 5): the name and domicile, intents and purposes, the type of cooperative and business sectors, membership, meeting the supervisory board members and managers, Capital, and the time period of Business. The manufacture or preparation of the deed of establishment of the cooperative can be made by the founders (in the case in the local area there are NPAK) or Notary Deed Cooperative (Article 6 paragraph 1). Furthermore Notary or authority Founder apply for endorsement in writing to the competent authorities with attached duplicate copy of the certificate of incorporation sufficiently stamped, the data deed of incorporation of a cooperative created and signed by a Notary, Authorized Officer will conduct research on the material Statutes proposed (Article 8, paragraph 2 ), checking the existence of the cooperative (Article 8, paragraph 2). If the petition is accepted, the attestation no later than 3 (three) months after the file is received in full (Article 9 Paragraph 2). If the petition is rejected, the rejection and the reasons Decision fed back to the power of the founder of a maximum of 3 (three) months after the application was filed (Article 12 Paragraph 1). 
Against Rejection, the founders can apply for re-issuance of the deed of establishment of cooperatives within a maximum period of 1 (one) month. The decision on the request is provided no later than 1 (one) month (Article 12 Paragraph 2). ${ }^{7}$ Once the requirements of the Department of Cooperatives met, the notary sends the files to the requirements for the establishment of cooperatives Cooperative Agency district using the latest online system. The cooperative for the authorization process for a period of a minimum of 6 working days and a maximum of 30 working days.

\subsection{Obstacles and Solutions in Implementing Cooperation Deed Under Act No. 25 of 1992 on Cooperatives in Kudus District}

Article 1 Regulation Minister No.1 of 2006 and Decree No.10 2015 KUKM Minister of Institutional governing cooperative official report and minutes of the meeting of the establishment. In the minutes of the cooperative must be signed by NPAK (Notary Deed Cooperative) as evidence and the minutes of the meeting the formation of cooperatives is the duty of a notary. very clearly in the rules have been set notaries participate in meetings of formation, but in the Kudus territory, especially the clients Mr. Soegiyanto or cooperative deed ever created no problem. But many other areas in the region found a notary is excluded by the founder and the Department of Cooperatives in formation meetings, so that each holding of a meeting of cooperative formation of cooperatives Department moves itself without the presence of a notary. Before meeting held formation, the founders came to the Office of the cooperative for consultation and choose the notary pilihanya itself according to the heart of the founder, if there is no option notary the Department of cooperatives provide recommendations notary choice.

Efforts are being made to overcome these constraints, namely: For the sake of legal certainty and legal protection for a notary and not to forget on a sense of fairness to all parties based on legislation that has been set should the Department of Cooperatives duty in accordance with the Act and regulations. Notary invited alongside founders in the meeting included the establishment of the cooperative.Cooperative Agency did not carry out their duties in accordance with the Law on the duties notary who recorded the results of the meetings and make the minutes on Article 1 point 10 and 11 of Decree of the Minister No.10 of 2015 on Institutional. If an error occurs in a deed written by the notary by the error comes from a letter written news or minutes at the Department does not reflect justice for notaries and legal certainty is clear in the regulations concerning notary task in meeting the formation of cooperatives. ${ }^{8}$

Article 3 of the Regulation of the Minister 12006 on the implementation of the formation, establishment and Approval of amendments of Regulation of Minister of Cooperatives and KUKM 102015 on Institutional and Legal Cooperation mention to prospective founders of the cooperative must understand before setting up Cooperatives, Article 15 of the Law on Notary Public Notary one of the Authority is to provide legal counseling to the parties on the deed that will be made and Act No.25 of 1992 Article 6 On Cooperatives.

From the results of my interview with Dr. Soegiyanto SH., M.Kn there are several candidates for the cooperative founders who came to the notary office to request the extension request legal knowledge as well as regulations on procedures for establishing cooperatives and on the Formation of Cooperatives and the type of its

\footnotetext{
${ }^{7}$ Dr. Soegiyanto SH., Notary PPAT M.Kn, personal interview, dated June 20, 2019 in Kudus, Jl. Kyai H.Agus Salim 234, Getas, Getas Housing, SPSS, Kudus

${ }^{8}$ Ibid.
} 
kind, while the notary public knowledge on cooperatives is still not fully or highly menguasau limited, especially for NPAK (Notary Deed cooperative) who had received sk's deed has not been so cooperative masiuh master concerning cooperatives.

Based on the theory of justice and legal certainty theory NPAK duties as a notary (Notary Deed Land) are required to provide legal counseling and provide insights into the cooperative to be able to provide jurisprudence that for the founder of cooperatives to cooperatives regulations aimed at schools

Efforts are being made to overcome these constraints, namely, that to the prospective founders of the cooperative understanding regarding cooperatives before establishing cooperative and understand the formation and terms. But in fact, not much of a notary who understands about cooperatives, especially procedures for the establishment of cooperatives through a notary, because in the law office of a notary already set about the task of notary including providing legal counseling to prospective clients before a deed or prospective founders of the cooperative before establishing a cooperative, although kenyatanya notary public knowledge about cooperatives is limited. For the sake of fairness and legal certainty and legal protection should Cooperatives and Notaries to the founders to provide knowledge about the cooperative so that more schools and prepared in all to set up a cooperative and understand about cooperatives. ${ }^{9}$

\section{Closing}

\subsection{Conclusion}

- Notary Act gives the sense of the Notaries in Article 1 (1) of Act No. 322014 amendment number 30 of 2004 that a Notary is a public official authorized to create certificates are authentic, Notary as NPAK set out in Article 4 of Decree of the Minister No. 98 Of 2004 regarding Notary Public as Cooperation Deed Official, that Notaries are General Authorities appointed under Regulation Notary, duly authorized by the Government to make the deed of establishment of cooperatives.

- In deed there are some constraints, namely cooperative notaries are excluded from the meeting the formation of cooperatives, cooperative joint founder of the cooperative department itself without a notary public meeting, the founders should include notary. And the founders of the cooperative were still not understand on Laws and regulations on cooperatives. whereas in Act clearly required to provide counseling notary laws and regulations on cooperatives, while notaries also there are some who have not mastered, should the notary must master the laws and regulations on cooperatives so that if the founders want consultation on legal counseling and regulations on cooperatives.

\subsection{Suggestion}

- Notary engage in cooperative formation meeting, since the fact that service cooperatives own conduct meetings with the founders of cooperatives. In a meeting of the founders of the formation of cooperatives and service cooperatives to conduct meetings while the formation of a notary is not in ikutsertakan, Article 1 of the Regulation of Minister No.1 of 2006 and Decree No.10 2015 KUKM Minister of Institutional governing cooperative official report and minutes of the meeting of the

\footnotetext{
${ }^{9}$ Ibid.
} 
establishment. In the minutes of the cooperative must be signed by NPAK (Notary Deed Cooperative) as evidence and the minutes of the meeting the formation of cooperatives is the duty of a notary. very clearly in the regulations have set the notary participated in the formation meeting.

- Notary must master the regulation of cooperatives so that if the founders want consultation on the regulation of cooperatives, notaries already mastered. Article 3 of the Regulation of the Minister 12006 on the implementation of the formation, establishment and Approval of amendments of Regulation of Minister of Cooperatives and KUKM 102015 on Institutional and Legal Cooperation mention to prospective founders of the cooperative must understand before setting up Cooperatives, Article 15 of the Law on Notary Public Notary one of the Authority is to provide legal counseling to the parties on the deed that will be made. Shrimp is very clear in the regulations of Law has arranged that the notary must provide information on the law or the rules of the cooperatives to the founders of the cooperative.

\section{Bibliography}

[1] Arliman S., Laurensius, 2015, Notaris dan Penegak Hukum oleh Hakim, Deepublish Publisher CV BUDI UTAMA, Yogyakarta

[2] Dr. Teuku Saiful Bahri Johan. 2012. Hukum Tata Negara Dan Hukum Administrasi Negara Dalam Tataran Reformasi Ketatanegaraan Indonesia, Cetakan pertama, CV BUDI UTAMA. DIY

[3] Dr. Soegiyanto SH., Notary PPAT M.Kn, personal interview, dated June 20, 2019 in Kudus, Jl. Kyai H.Agus Salim 234, Getas, Getas Housing, SPSS, Kudus

[4] Internet, the Constitution Court's decision on the cancellation of Act No.25 of 2012 on Cooperatives

[5] Cooperatives Decree No. 98 / KEP / M.KUKM / IX / 2004 on Notary Deed Cooperative

[6] Act No.25 of 1992 concerning Cooperatives

[7] Act No.17 of 2012 on Cooperatives

[8] UKM Syarifudin Hasan. 2012. Realisasi Revisi UU No 25 Tahun 1992

[9] Sitepu, C.F. dan Hasyim, 2018, Perkembangan Ekonomi Koperasi Di Indonesia, NIAGAWAN, 7(2): 58-68. 